\title{
PENERAPAN PEMBELAJARAN OPEN ENDED UNTUK MENGETAHUI HASIL BELAJAR PESERTA DIDIK PADA MATERI BANGUN RUANG SISI DATAR KELAS VIII-D SMP NEGERI 26 SURABAYA TAHUN PELAJARAN 2015-2016
}

\author{
Indah Sulistyaningsih \\ SMPN 26 Surabaya \\ e-mail: istya.math@gmail.com
}

\begin{abstract}
Abstrak: Untuk menyelesaikan soal-soal matematika diperlukan langkah-langkah lain seperti: memahami masalah, merencanakan penyelesaian. Namun kemampuan pemecahan masalah siswa masih kurang aktif dan kreatif. Model pembelajaran yang sesuai adalah open ended karena open ended pendekatan pembelajarannya memberikan keleluasaan berpikir peserta didik secara aktif dan kreatif. Pendidikan karakter peserta didik mengalami peningkatan melalui penerapan pembelajaran open ended, dapat dilihat dari data siklus I; 61,86 (sedang) dan pada siklus II menjadi 72,73 (tinggi). Kualitas pembelajaran oleh guru matematika mengalami peningkatan dari skor perolehan pada siklus I sebesar 65,00\% (sedang) dan pada siklus II menjadi 76,00\% (baik). Penguasaan siswa terhadap materi melalui pembelajaran open ended dengan nilai rata-rata kelas 79,09 pada siklus pertama menjadi 89,47 pada siklus kedua.
\end{abstract}

Kata kunci: hasil belajar, peserta didik, pembelajaran open ended

\begin{abstract}
To solve math problems, other steps are needed, such as: understanding the problem, planning a solution. But the problem solving ability of students is still less active and creative. . The appropriate learning model is open ended because the open ended learning approach gives students the freedom to think actively and creatively. Character education of students has increased through the application of open ended learning, can be seen from the data of cycle I; 61.86 (moderate) and in the second cycle it was 72.73 (high). The quality of learning by mathematics teachers has increased from the acquisition score in the first cycle of $65.00 \%$ (medium) and in the second cycle to $76.00 \%$ (good). Mastery of students towards the material through open ended learning with an average grade of 79.09 in the first cycle to 89.47 in the second cycle.
\end{abstract}

Keywords: learning outcomes, learners, and open ended learning

\section{PENDAHULUAN}

Permasalahan klasik pada mata pelajaran matematika adalah peserta didik masih kesulitan dalam menerima pelajaran matematika karena dianggap sebagai mata pelajaran yang menakutkan sekaligus sulit dipahami. Menurut pendapat Marpaung (2003:2) matematika dianggap sulit karena: (1) pada umumnya peserta didik takut pada pelajaran matematika, (2) matematika dianggap sulit, abstrak, dan tak bermakna, (3) pelajaran matematika membuat peserta didik stress, (4) bahan yang dipelajari terlalu banyak, (5) matematika penuh dengan rumus-rumus, (6) guru matematika umumnya galak, dan (7) serius dan kurang menyenangkan. Hal ini pula yang terjadi di SMP Negeri 26 Surabaya. Walaupun sekolah tersebut berada di kota besar dengan fasilitas yang cukup memadai tetapi tidak semua peserta didik mempunyai kemampuan yang unggul, masih banyak masalah matematika yang 
dialami para peserta didik terutama dalam materi bangun ruang.

Pembelajaran matematika di sekolah ini juga masih cenderung pada pembelajaran ekspositori, di mana sebagian besar kegiatan belajar mengajar masih didominasi oleh guru yang secara aktif mengajarkan matematika, satu jawaban yang benar (konvergen). Menurut Sagala (2006: 79) pendekatan ekspositori adalah pendekatan yang menempatkan guru sebagai pusat pengajaran yang menunjukkan guru berperan lebih aktif dan lebih banyak melakukan aktivitas dibanding peserta didiknya karena guru telah menyiapkan bahan ajar secara tuntas sedangkan peserta didik hanya menerima bahan ajaran yang disampaikan guru.

Kemampuan pemecahan masalah peserta didik juga belum bisa dikatakan membanggakan, dari jawaban-jawaban tersebut diketahui bahwa peserta didik mengerjakan suatu soal hanya dengan satu cara, yaitu sesuai dengan cara yang diajarkan oleh gurunya, tidak semua peserta didik ingat untuk menyimpulkan jawaban akhir, sedangkan untuk langkah-langkah lain seperti: memahami masalah (menuliskan diketahui dan ditanyakan dalam soal), serta merencanakan penyelesaian (menentukan rumus, menuliskan rumus) sudah dilakukan oleh peserta didik. Kemampuan pemecahan masalah siswa masih kurang aktif dan kreatif. Keadaan ini menuntut pembelajaran juga harus disesuaikan dengan model pembelajaran yang digunakan. Salah satu model pembelajaran yang sesuai adalah open ended. Open ended yaitu suatu pendekatan pembelajaran yang memberikan keleluasaan berpikir pada peserta didik secara aktif dan kreatif. Selain itu, di SMP Negeri 26 Surabaya masih ada peserta didik yang belum menerapkan pendidikan karakter di sekolah, terutama saat sedang berlangsung mata pelajaran matematika. Jadi pada penelitian ini akan menggunakan metode pembelajaran open ended yang bermuatan pendidikan karakter guna membenahi karakter peserta didik yang dirasa menurun kualitasnya.

Agar penelitian dapat terarah dan mencapai hasil yang diinginkan, maka diperlukan rumusan masalah yang menjadi dasar dan acuan dalam pelaksanaan penelitian. Adapun rumusan masalah dalam penelitian ini adalah sebagai berikut. (1) Apakah hasil belajar peserta didik kelas VIII D SMP Negeri 26 Surabaya dengan menerapkan model pembelajaran open ended bermuatan pendidikan karakter mencapai kriteria ketuntasan minimal (KKM)? (2) Apakah kemampuan pemecahan masalah peserta didik Kelas VIII D SMP Negeri 26 Surabaya dalam model pembelajaran open ended bermuatan pendidikan karakter lebih tinggi dari pada kemampuan pemecahan masalah peserta didik dalam model pembelajaran ekspositori? (3) Apakah nilai kejujuran, kedisiplinan, dan rasa keingintahuan peserta didik kelas VIII D SMP negeri 26 Surabaya dengan menerapkan model pembelajaran open ended bermuatan pendidikan karakter lebih baik daripada peserta didik dengan menggunakan model pembelajaran ekspositori? Dengan penerapan model pembelajaran open ended diharapkan (1) Untuk mengetahui apakah hasil belajar peserta didik Kelas VIII D SMP Negeri 26 Surabaya dengan menerapkan model pembelajaran open ended bermuatan pendidikan karakter mencapai kriteria ketuntasan minimal (KKM) klasikal minimal 80\%. (2) Untuk mengetahui apakah kemampuan pemecahan masalah peserta didik Kelas VIII D SMP Negeri 26 Surabaya dalam model pembelajaran open ended bermuatan pendidikan karakter lebih tinggi daripada kemampuan pemecahan masalah peserta didik dalam model pembelajaran ekspositori. (3) Untuk mengetahui apakah nilai kejujuran, kedisiplinan, dan rasa keingintahuan peserta didik Kelas VIIID SMP Negeri 26 Surabaya dengan menerapkan 
model pembelajaran open ended bermuatan pendidikan karakter lebih baik daripada peserta didik dengan menggunakan model pembelajaran ekspositori.

\section{TINJAUAN PUSTAKA}

Pengertian karakter menurut Pusat Bahasa Depdiknas sebagaimana dikutip oleh Amri (2011: 3) adalah bawaan, hati, jiwa, kepribadian, budi pekerti, perilaku, personalitas, sifat, tabiat, temperamen, watak. Menurut Mumpuniarti (2012: 252) karakter adalah ciri-ciri tingkah laku seseorang yang menandai individu berbeda dengan individu lainnya dan mencirikan seseorang dalam merespons situasi dan kondisi sosial yang dihadapi. Sedangkan pendidikan karakter adalah segala sesuatu yang dilakukan guru, yang mampu memengaruhi karakter peserta didik. Secara akademis, menurut Lickona sebagaimana dikutip Ikhwanuddin (2012: 154) pendidikan karakter dimaknai sebagai pendidikan nilai, pendidikan budi pekerti, pendidikan moral, pendidikan watak, atau pendidikan akhlak yang tujuannya mengembangkan kemampuan peserta didik untuk memberikan keputusan baik-buruk, memelihara apa yang baik, dan mewujudkan kebaikan tersebut dalam kehidupan sehari-hari dengan sepenuh hati.

Pendidikan karakter digunakan sebagai usaha sengaja guru untuk mengembangkan kebajikan kepada peserta didik. Guru membantu membentuk watak peserta didik. Sebagaimana dikutip oleh Lestyarini (2012: 348), menurut Komarudin Hidayat seorang guru perlu melakukan life's journey yaitu upaya memahami kecenderungan sifat-sifat dasar watak atau karakter manusia. Hal ini mencakup keteladanan bagaimana perilaku guru, cara guru berbicara atau menyampaikan materi, bagaimana guru bertoleransi, dan berbagai hal terkait lainnya. Menurut
Ramli sebagaimana dikutip oleh Amri (2011: 4) pendidikan karakter memiliki esensi dan makna yang sama dengan pendidikan moral dan pendidikan akhlak. Tujuannya adalah membentuk pribadi anak supaya menjadi manusia yang baik, warga masyarakat dan warga negara yang baik. Schwartz sebagaimana dikutip oleh Ikhwanuddin (2012: 154) mengemukakan bahwa pendidikan karakter sering digunakan untuk merujuk bagaimana seseorang menjadi "baik", yaitu menunjukkan kualitas pribadi yang sesuai dengan yang diinginkan masyarakat. Identitas diri anak sebagai wujud pembentukan karakter anak dan perkembangannya akan dipengaruhi lingkungan sekitarnya, termasuk lingkungan sekolah (Idrus, 2012: 120). Menurut Rosada sebagaimana dikutip Suhardi (2012: 319) menjelaskan bahwa karakter dapat dikembangkan melalui tahap pengetahuan (knowing), bertindak (acting), dan menuju kebiasaan (habit). Karakter bukan hanya sebatas pada pengetahuan saja, tetapi perlu adanya perlakuan dan kebiasaan untuk berbuat. Sedangkan menurut Sudrajat sebagaimana dikutip Mumpuniarti (2012: 254), ada empat cara untuk mengimplementasikan karakter di sekolah, yaitu (1) pembelajaran; (2) keteladanan; (3) penguatan; dan (4) pembiasaan.

Keberhasilan pendidikan karakter akan dipengaruhi oleh teladan dan contoh nyata dalam kehidupan dan dalam kegiatan pembelajaran. Dalam pendidikan karakter di sekolah, semua komponen (stakeholders) harus dilibatkan, termasuk komponen-komponen pendidikan itu sendiri, yaitu isi kurikulum, proses pembelajaran dan pendidikan, kualitas hubungan, penanganan atau pengelolaan mata pelajaran, pengelolaan sekolah, pelaksanaan aktivitas atau kegiatan kokurikuler, pemberdayaan sarana prasarana, pembiayaan, dan ethos kerja seluruh warga dan lingkungan sekolah. 
Konsep tentang belajar telah banyak didefinisikan oleh para pakar. Piaget sebagaimana dikutip Sugandi (2004:35), mengemukakan tiga prinsip pembelajaran, yaitu belajar aktif, belajar lewat interaksi sosial, dan belajar lewat pengalaman sendiri. Sedangkan J.A. Brunner sebagaimana dikutip Sugandi (2004:36) menyatakan bahwa dalam belajar ada empat hal pokok yang perlu diperhatikan, yaitu peranan pengalaman struktur pengetahuan, kesiapan mempelajari sesuatu, intuisi, dan cara membangkitkan motivasi belajar. Dalam penelitian ini, peserta didik diarahkan untuk mengonstruk pengetahuannya sendiri dengan cara mengembangkan pengetahuan yang sudah dimiliki sebelumnya.

Konstruktivisme merupakan proses pembelajaran yang menerangkan bagaimana pengetahuan disusun dalam diri manusia (Hapsari, 2011: 35). Sedangkan menurut Von Glasersfeld sebagaimana dikutip Suparno (1997: 23) mengatakan bahwa konstruktivisme adalah salah satu filsafat pengetahuan yang menekankan bahwa pengetahuan kita adalah konstruksi (bentukan) kita sendiri. Pengetahuan itu dibentuk oleh struktur konsepsi seseorang sewaktu berinteraksi dengan lingkungannya. Dasar dari pandangan konstruktivistik adalah anggapan bahwa dalam proses belajar: (a) peserta didik tidak menerima begitu saja pengetahuan yang didapatkan mereka dan menyimpannya di kepala, melainkan mereka menerima informasi dari dunia sekelilingnya, kemudian membangun pandangan mereka sendiri tentang pengetahuan yang mereka dapatkan; dan (b) semua pengetahuan disimpan dan digunakan oleh setiap orang melalui pengalaman yang berhubungan dengan ranah pengetahuan tertentu (Fachrurrazy, 2002: 1-2).

Menurut Suherman (2003: 124) pendekatan open ended adalah pembelajaran dengan pendekatan terbuka yang memberikan kebebasan indi- vidu untuk mengembangkan berbagai cara dan strategi pemecahan masalah sesuai dengan kemampuan masing-masing peserta didik. Kegiatan pembelajaran harus membawa peserta didik dalam menjawab permasalahan dengan banyak cara dan mungkin juga banyak jawaban (yang benar) sehingga mengundang potensi intelektual dan pengalaman peserta didik dalam proses menemukan sesuatu. Menurut Inprasitha (2006: 170171) pada pendekatan open ended, guru memberikan peserta didik soal yang mempunyai solusi tidak tunggal. Kemudian guru membuat soal yang bermacam-macam dengan harapan dapat memberikan peserta didik pengalaman dalam menemukan sesuatu yang baru dengan mengombinasikan pengetahuan, keterampilan, dan cara berpikir matematis yang telah mereka miliki sebelumnya.

Tujuan dari pembelajaran open ended menurut Nohda sebagaimana dikutip Kusmiyati (2007: 2) yaitu membawa peserta didik lebih mengembangkan kegiatan kreatif dan pola pikir matematisnya melalui problem solving secara simultan. Dengan kata lain kegiatan kreatif dan pola pikir matematis peserta didik harus dikembangkan semaksimal mungkin sesuai dengan kemampuan setiap peserta didik. Pokok pikiran pembelajaran dengan open ended yaitu pembelajaran yang membangun kegiatan interaktif antara matematika dan peserta didik sehingga mengundang peserta didik untuk menjawab permasalahan melalui berbagai strategi (Nurdin \& Paduppai, 2008: 912). Menurut Swada sebagaimana dikutip Wahyuningsih (2006: 27) pendekatan open ended memiliki keunggulan dan kelemahan. Keunggulan yang dimaksud adalah sebagai berikut.

a) Peserta didik berperan lebih aktif dalam pembelajaran dan lebih sering menyatakan pendapatnya. 
b) Peserta didik mendapat kesempatan lebih untuk menggunakan keterampilan matematika secara komprehensif.

c) Peserta didik berkemampuan rendah dapat memberi jawaban menurut caranya sendiri.

d) Peserta didik secara intrinsik termotivasi untuk membuktikan.

e) Peserta didik memperoleh banyak pengalaman dalam menemukan dan menerima pengakuan dari teman lain.

Kelemahan pendekatan open ended sebagai berikut.

a) Sukar untuk membuat situasi soal yang bermakna.

b) Sukar bagi guru untuk menyajikan soal secara jelas.

c) Sering kali peserta didik mengalami kesulitan memahami bagaimana harus menjawab soal benar secara matematis.

Sintaks dari model pembelajaran open ended adalah menyajikan masalah, pengorganisasian pembelajaran, memperhatikan dan mencatat respons peserta didik, melakukan bimbingan dan pengarahan, lalu membuat kesimpulan.

Dalam pendekatan open ended, guru memberi peserta didik soal yang mempunyai solusi tunggal. Kemudian guru membuat soal yang bermacam-macam dengan harapan dapat memberikan peserta didik pengalaman dalam menemukan sesuatu yang baru dengan mengombinasikan pengetahuan, keterampilan, dan cara berpikir matematis yang telah mereka miliki sebelumnya.

Menurut Swada sebagaimana dikutip Wahyuningsih (2006: 27) pendekatan open ended memiliki keunggulan dan kelemahan. Keunggulan yang dimaksud adalah sebagai berikut.

a) Peserta didik berperan lebih aktif dalam pembelajaran dan lebih sering menyatakan pendapatnya. b) Peserta didik mendapat kesempatan lebih untuk menggunakan keterampilan matematika secara komprehensif.

c) Peserta didik berkemampuan rendah dapat memberi jawaban menurut caranya sendiri.

d) Peserta didik secara intrinsik termotivasi untuk membuktikan.

e) Peserta didik memperoleh banyak pengalaman dalam menemukan dan menerima pengakuan dari teman lain.

Kelemahan pendekatan open ended adalah sebagai berikut.

a) Sukar untuk membuat situasi soal yang bermakna.

b) Sukar bagi guru untuk menyajikan soal secara jelas.

c) Sering kali peserta didik mengalami kesulitan memahami bagaimana harus menjawab soal benar secara matematis.

Sintaks dari model pembelajaran open ended adalah menyajikan masalah, pengorganisasian pembelajaran, memperhatikan dan mencatat respons peserta didik, melakukan bimbingan dan pengarahan, lalu membuat kesimpulan.

\section{METODE}

Kelas yang menjadi objek penelitian ini adalah siswa kelas VIII D sebanyak 38 orang siswa, subjek penelitian meliputi laki-laki dan perempuan. Jumlah siswa laki-laki 18 orang dan perempuan 20 orang untuk tahun pelajaran 2015-2016. Penelitian dilaksanakan pada bulan Februari sampai Maret 2016.

Waktu pelaksanaan penelitian pada mata pelajaran matematika dengan kompetensi dasar (KD) mendeskripsikan bangun ruang sisi datar meliputi hal-hal sebagai berikut. 
a) Membedakan dan menentukan luas permukaan dan volume bangun ruang sisi datar (kubus, balok, prisma, dan limas).

b) Menyelesaikan masalah yang berkaitan dengan luas permukaan dan volume bangun ruang sisi datar (kubus, balok, prisma, dan limas).

Penelitian ini dilaksanakan dalam 2 siklus. Masing-masing siklus terdiri dari 4 pertemuan. Setiap siklus, terdiri dari 4 tahapan, yaitu perencanaan, pelaksanaan, observasi, dan refleksi.

Pengumpulan data dilakukan pada setiap siklus, yaitu pada siklus 1 dan II. Pengumpulan data dilakukan dengan menggunakan metode sebagai berikut.

\section{Observasi}

Observasi yang digunakan adalah observasi eksperimental. Catatan lapangan untuk mencatat suasana kelas selama proses pembelajaran berlangsung, untuk merekam jalannya proses pembelajaran.

\section{Tabel 1 Pendidikan Karakter Siswa}

\begin{tabular}{|c|l|l|l|l|l|l|l|}
\hline \multirow{2}{*}{ No. } & \multicolumn{2}{|c|}{ Karakter } & \multicolumn{7}{c|}{ Skor } & Jumlah \\
\hline & & 1 & 2 & 3 & 4 & 5 & \\
\hline 1 & Religius & & & & & & \\
\hline 2 & Jujur & & & & & & \\
\hline 3 & Toleransi & & & & & & \\
\hline 4 & Disiplin & & & & & & \\
\hline 5 & Kerja keras & & & & & & \\
\hline 6 & Kreatif & & & & & & \\
\hline 7 & Mandiri & & & & & & \\
\hline 8 & Demokratis & & & & & & \\
\hline 9 & Rasa ingin tahu & & & & & & \\
\hline 10 & Semangat Kebangsaan & & & & & & \\
\hline 11 & Menghargai prestasi & & & & & & \\
\hline 12 & Cinta tanah air & & & & & & \\
\hline 13 & Bersahabat & & & & & & \\
\hline 14 & Cinta damai & & & & & & \\
\hline 15 & Gemar membaca & & & & & & \\
\hline 16 & Peduli lingkungan & & & & & & \\
\hline 17 & Peduli sosial & & & & & & \\
\hline 18 & Tanggung jawab & & & & & & \\
\hline & Skor & & & & & & \\
\hline & Rata-rata & & & & & & \\
\hline & Kriteria & & & & & & \\
\hline
\end{tabular}

Keterangan:

$$
\begin{aligned}
& 1=\text { Sangat Rendah } \\
& 2=\text { Rendah } \\
& 3=\text { Sedang } \\
& 4=\text { Tinggi } \\
& 5=\text { Sangat Tinggi }
\end{aligned}
$$

Rumus yang digunakan persentasenya adalah:

$$
\mathrm{N}=\mathrm{R} / \mathrm{SM} \mathrm{X} 100
$$

Keterangan:

$\mathrm{N}=$ Nilai dalam persen

$\mathrm{R}=$ Skor nyata yang dicapai

SM $=$ Skor ideal (Ngalim Purwanto, 2001: 102)

Nilai persentase yang diperoleh selanjutnya dibandingkan dengan kriteria persentase untuk ditarik kesimpulan. Adapun langkah-langkah pembuatan kriteria persentase adalah sebagai berikut:

Persentase skor maksimal $=(4: 4) \times 100 \%=$ $100 \%$

Persentase skor minimum $=(1: 4) \times 100 \%=$ $25 \%$

Rentang persentase skor $=100 \%-25 \%=75 \%$ Banyaknya kriteria $=5$ (sangat rendah, rendah, sedang, tinggi, sangat tinggi)

Panjang kelas interval = rentang: banyaknya interval $=75 \%: 5=15 \%$

Tabel 2 Kriteria Penilaian

\begin{tabular}{|c|c|}
\hline INTERVAL & KRITERIA \\
\hline $85 \%-100 \%$ & Sangat Tinggi \\
\hline $70 \%-85 \%$ & Tinggi \\
\hline $55 \%-70 \%$ & Sedang \\
\hline $40 \%-55 \%$ & Rendah \\
\hline $25 \%-40 \%$ & Sangat Rendah \\
\hline
\end{tabular}

\section{Dokumentasi}

Dokumentasi dipergunakan untuk mendokumentasikan hasil-hasil pekerjaan siswa yang dipandu dengan format pembelajaran. 


\section{Tes}

Jenis tes yang digunakan oleh peneliti dalam penelitian ini adalah tes prestasi atau achievement test.

Untuk analisis data, yang dilakukan meliputi tiga langkah, yakni: (1) persiapan, (2) tabulasi dan (3) penerapan data sesuai dengan pendekatan pelaksanaan penelitian. Pada kegiatan analisis nantinya peneliti akan memperoleh dua jenis data, yaitu data kualitatif dan data kuantitatif. Data kualitatif diperoleh dari metode observasi dan dokumentasi, sedangkan data kuantitatif diperoleh dari metode tes.

Hasil analisis tersebut nantinya dapat peneliti gunakan sebagai dasar untuk menarik kesimpulan dan sekaligus sebagai dasar untuk melakukan refleksi.

Indikator keberhasilan tiap-tiap siklus ditentukan oleh dua hal berikut.

1) Keberhasilan dalam proses pembelajaran yang dikenal dengan evaluasi proses.

2) Keberhasilan dalam produk atau efek yang dihasilkan oleh siswa sesuai dengan tujuan pembelajaran yang telah dirancang, yang dikenal dengan evaluasi produk.

Keberhasilan dalam evaluasi proses ditandai dengan indikator bahwa dalam pelaksanaan materi dengan penilaian proyek jawaban siswa harus benar dan secara klasikal kebenaran jawaban tersebut harus mencapai 85\%. Sedangkan dalam evaluasi produk, ditandai dengan indikator bahwa nilai hasil belajar siswa harus mencapai nilai KKM: 80, dan secara klasikal harus mencapai $85 \%$.

\section{HASIL DAN PEMBAHASAN}

\section{Hasil Penelitian Siklus I}

Tabel 3 Pendidikan Karakter Siswa Siklus I

\begin{tabular}{|c|l|c|c|c|c|c|c|}
\hline \multirow{2}{*}{ No. } & \multirow{2}{*}{ Karakter } & \multicolumn{7}{|c|}{ Skor } & Jumlah \\
\cline { 3 - 8 } & & $\mathbf{1}$ & $\mathbf{2}$ & $\mathbf{3}$ & $\mathbf{4}$ & $\mathbf{5}$ & \\
\hline 1 & Religius & 0 & 0 & 30 & 8 & 0 & 122 \\
\hline 2 & Jujur & 0 & 6 & 23 & 9 & 0 & 117 \\
\hline 3 & Toleransi & 0 & 1 & 14 & 10 & 13 & 149 \\
\hline 4 & Disiplin & 0 & 1 & 17 & 18 & 2 & 135 \\
\hline 5 & Kerja Keras & 0 & 2 & 20 & 15 & 1 & 129 \\
\hline 6 & Kreatif & 0 & 1 & 17 & 18 & 2 & 135 \\
\hline 7 & Mandiri & 0 & 2 & 20 & 12 & 4 & 132 \\
\hline 8 & Demokratis & 0 & 0 & 28 & 2 & 8 & 132 \\
\hline 9 & Rasa Ingin Tahu & 0 & 0 & 28 & 8 & 2 & 126 \\
\hline 10 & Semangat kebangsaan & 0 & 1 & 28 & 9 & 0 & 122 \\
\hline 11 & Menghargai prestasi & 0 & 2 & 20 & 8 & 8 & 136 \\
\hline 12 & Cinta tanah air & 0 & 1 & 19 & 10 & 8 & 139 \\
\hline 13 & Bersahabat & 0 & 0 & 28 & 2 & 8 & 132 \\
\hline 14 & Cinta damai & 0 & 1 & 30 & 7 & 0 & 120 \\
\hline 15 & Gemar membaca & 0 & 2 & 17 & 16 & 3 & 132 \\
\hline 16 & Peduli lingkungan & 0 & 2 & 16 & 12 & 8 & 138 \\
\hline 17 & Peduli social & 0 & 0 & 30 & 8 & 0 & 122 \\
\hline 18 & Tanggung Jawab & 0 & 1 & 22 & 10 & 5 & 133 \\
\hline & Skor & & & & & & 2.351 \\
\hline & Rata-rata & & & & & & 61,86 \\
\hline & Krikteria & & & & & & Sedang \\
\hline
\end{tabular}

Pelaksanaan pembelajaran matematika pada siklus I capaian pendidikan karakter siswa mencapai rata-rata skor 61,868 atau kriteria Sedang.

Melaksanakan tes untuk mengukur keberhasilan siswa. Guru juga menginformasikan adanya tes di akhir pertemuan untuk mengukur keberhasilan siswa. Jumlah soal dalam tes berjumlah 10.

\section{Hasil Penelitian Siklus II}

Kegiatan yang dilaksanakan pada siklus II pada dasarnya sama dengan kegiatan yang dilaksanakan pada siklus I. Kegiatan pada siklus II merupakan kelanjutan dari kegiatan siklus I. Kekurangan yang ada pada siklus I berusaha diperbaiki guna memaksimalkan pembelajaran pada siklus II.

Beberapa perbaikan yang dilakukan pada siklus II ini adalah sebagai berikut.

1) Untuk mengurangi egoisme siswa yang pandai, guru berusaha membimbing dan mengingatkan 
bahwa keberhasilan kelompok ditentukan juga oleh keberhasilan individu.

2) Agar pelaksanaan diskusi kelompok lebih aktif, maka anggota kelompok lebih dimaksimalkan dalam menyelesaikan tugas.

3) Untuk membantu siswa yang daya ingatnya lemah maka kertas pengingat tetap digunakan kertas pengingat hanya sewaktu-waktu bilamana diperlukan.

Pelaksanaan pembelajaran matematika pada siklus II capaian pendidikan karakter siswa mencapai rata-rata skor 72,736 atau kriteria Tinggi.

Kemampuan pemecahan masalah pada penelitian ini adalah kemampuan yang ditunjukkan peserta didik dalam menyelesaikan masalah matematika yang meliputi proses memahami masalah, membuat rencana penyelesaian, melakukan perhitungan, dan menyimpulkan.

Guru juga menginformasikan adanya tes di akhir pertemuan untuk mengukur keberhasilan siswa. Jumlah soal dalam tes berjumlah 10 . Siswa dalam mengerjakan tampak lebih lancar, karena sudah menguasai materi pembelajaran.

Tabel 4 Nilai Evaluasi Siklus I dan II Siswa dengan Menggunakan Penerapan Pembelajaran Open Ended

\begin{tabular}{|c|l|c|c|}
\hline \multirow{2}{*}{ No. } & \multicolumn{2}{|c|}{ Nama Siswa } & \multicolumn{2}{|c|}{ Nilai } \\
\cline { 3 - 4 } & & $\begin{array}{c}\text { Post } \\
\text { Test } 1\end{array}$ & $\begin{array}{c}\text { Post } \\
\text { Test 2 }\end{array}$ \\
\hline 1. & Achnaf Rifqi & 90 & 90 \\
\hline 2. & Ade Nia & 85 & 95 \\
\hline 3. & Ahmad S. & 90 & 100 \\
\hline 4. & Alfian Firmansyah & 85 & 95 \\
\hline 5. & Alifah Putri B. & 85 & 80 \\
\hline 6. & Andina Ariani & 85 & 100 \\
\hline 7. & Anjania Azalea & 85 & 95 \\
\hline 8. & Arfian Mulia B. & 85 & 95 \\
\hline 9. & Athasa Ayunda & 80 & 95 \\
\hline 10 & Benedicta G. & 70 & 85 \\
\hline 11 & Bintang Apriano & 65 & 100 \\
\hline 12 & Dimas Aditya & 70 & 95 \\
\hline 13 & Dita Arrizki & 70 & 70 \\
\hline 14 & Dodi Yuli & 65 & 90 \\
\hline
\end{tabular}

\begin{tabular}{|c|l|c|c|}
\hline 15 & Dwi Ayu N. & 75 & 95 \\
\hline 16 & Eudia Lavita & 90 & 85 \\
\hline 17 & Fahrel Fahriza & 80 & 80 \\
\hline 18 & Fiqih Riski & 85 & 100 \\
\hline 19 & Gita Anggraeni & 75 & 70 \\
\hline 20 & Intan Rizki & 90 & 90 \\
\hline 21 & Kurnia Hidayat & 80 & 85 \\
\hline 22 & Lia Anggraeni & 80 & 80 \\
\hline 23 & M. Fahmi Nur & 80 & 90 \\
\hline 24 & Mochammad Rizki & 70 & 80 \\
\hline 25 & Muhammad Hadyan & 85 & 90 \\
\hline 26 & Naomi Ariyanti & 80 & 80 \\
\hline 27 & Novira Damayanti & 80 & 85 \\
\hline 28 & Pratiwi Angga & 85 & 80 \\
\hline 29 & Rahma Azis & 80 & 95 \\
\hline 30 & Rizky Esa & 80 & 80 \\
\hline 31 & Rusyanrianto W. & 90 & 80 \\
\hline 32 & Salis Zuhroh & 65 & 85 \\
\hline 33 & Shelsa Widya & 65 & 80 \\
\hline 34 & Suci Selva & 75 & 90 \\
\hline 35 & Sutrisno Akmal & 82 & 82 \\
\hline 36. & Wahyu Yoga & 80 & 80 \\
\hline 37. & Wulan Aprisyah & 80 & 80 \\
\hline 38. & Zumrotul M & 60 & 80 \\
\hline & Jumlah Nilai & 3.005 & 3.302 \\
\hline & Rata-rata kelas & 79,08 & 86,89 \\
\hline & Persentase Ketuntasan & $71,06 \%$ & $89,47 \%$ \\
\hline
\end{tabular}

Untuk menghitung rata-rata kelas digunakan rumus:

$\mathrm{X}=\frac{\Sigma x}{N}$

Keterangan:

$\mathrm{X}=$ Rata-rata (mean)

$\Sigma \mathrm{x}=$ Jumlah seluruh nilai

$\mathrm{N}=$ Banyaknya subjek (siswa)

Jadi, rata-rata untuk post tes pada siklus I adalah:

$\mathrm{X}=\frac{\Sigma \mathrm{x}}{N}$

$X=3.005: 38$

$X=79,08$

Sedangkan rata-rata untuk post tes pada siklus II adalah:

$\mathrm{X}=\frac{\sum \mathrm{x}}{N}$

$X=3.282: 38$

$X=86,37$ 
Untuk menghitung persentase prestasi belajar digunakan rumus:

$P=\frac{\mathrm{f}}{\mathrm{N}} \times 100 \%$

Keterangan:

$\mathrm{P}=$ Persentase yang akan dicari

$\mathrm{f}=$ Jumlah siswa yang tuntas

$\mathrm{N}=$ Jumlah seluruh siswa

Jadi, persentase ketuntasan pada siklus I adalah:

$P=\frac{\mathrm{f}}{\mathrm{N}} \times 100 \%$

$P=\frac{27}{38} \times 100 \%$

$P=71,06 \%$

Sedangkan persentase prestasi belajar pada siklus II adalah:

$$
\begin{aligned}
& P=\frac{\mathrm{f}}{\mathrm{N}} \times 100 \% \\
& P=\frac{34}{38} \times 100 \% \\
& P=89,47 \%
\end{aligned}
$$

\begin{tabular}{|c|c|c|c|c|c|c|c|}
\hline \multirow{2}{*}{ No. } & \multirow{2}{*}{ Karakter } & \multicolumn{5}{|c|}{ Skor } & \multirow[t]{2}{*}{ Jumlah } \\
\hline & & 1 & 2 & 3 & 4 & 5 & \\
\hline 1 & Religius & 0 & 0 & 21 & 8 & 9 & 140 \\
\hline 2 & Jujur & 0 & 2 & 14 & 12 & 10 & 144 \\
\hline 3 & Toleransi & 0 & 0 & 11 & 9 & 18 & 159 \\
\hline 4 & Disiplin & 0 & 0 & 15 & 15 & 8 & 145 \\
\hline 5 & Kerja keras & 0 & 0 & 6 & 12 & 20 & 166 \\
\hline 6 & Kreatif & 0 & 0 & 10 & 18 & 10 & 152 \\
\hline 7 & Mandiri & 0 & 0 & 9 & 29 & 0 & 143 \\
\hline 8 & Demokratis & 0 & 0 & 17 & 10 & 11 & 146 \\
\hline 9 & Rasa Ingin Tahu & 0 & 0 & 16 & 4 & 18 & 154 \\
\hline 10 & Semangat Kebangsaan & 0 & 1 & 14 & 23 & 0 & 136 \\
\hline 11 & Menghargai prestasi & 0 & 0 & 2 & 28 & 8 & 158 \\
\hline 12 & Cinta tanah air & 0 & 0 & 0 & 12 & 26 & 178 \\
\hline 13 & Bersahabat & 0 & 0 & 19 & 29 & 0 & 173 \\
\hline 14 & Cinta damai & 0 & 0 & 25 & 13 & 0 & 127 \\
\hline 15 & Gemar Membaca & 0 & 1 & 17 & 1 & 19 & 154 \\
\hline 16 & Peduli Lingkungan & 0 & 1 & 8 & 17 & 12 & 154 \\
\hline 17 & Peduli Sosial & 0 & 0 & 8 & 30 & 0 & 164 \\
\hline \multirow[t]{4}{*}{18} & Tanggung Jawab & 0 & 0 & 9 & 19 & 10 & 171 \\
\hline & Skor & & & & & & 2.764 \\
\hline & Rerata & & & & & & 72,73 \\
\hline & Kriteria & & & & & & Tinggi \\
\hline
\end{tabular}

Tabel 5 Pendidikan Karakter Siswa pada Siklus II
Dari perhitungan di atas, diketahui bahwa pada siklus pertama rata-rata kelas cukup baik dengan angka 79,08 dan persentase ketuntasannya pada siklus I mencapai $71,06 \%$, besarnya persentase ini masih belum dikatakan tuntas karena standar ketuntasan seperti yang dijelaskan sebelumnya adalah mencapai $85 \%$. Pada siklus kedua nilai rata-rata siswa meningkat menjadi 86,37 atau dapat dikategorikan baik, begitu juga dengan persentase prestasi belajar pada siklus II mencapai $86,85 \%$ dan angka tersebut termasuk tuntas (kategori baik).

\section{Pembahasan}

Dari hasil kegiatan model pembelajaran dengan penilaian proyek yang telah dilakukan selama 2 (dua) siklus, diperoleh beberapa temuan hasil tindakan sebagai berikut.

1. Hasil yang diperoleh menunjukkan penerapan pembelajaran open ended berjalan dengan baik melalui perbaikan-perbaikan pada tiap siklus. Pada siklus pertama, penerapan pembelajaran tersebut memberikan motivasi yang baik terhadap pembelajaran yang dilakukan dengan pemahaman tentang KD mendeskripsikan bangun ruang sisi datar. 3.9. Membedakan dan menentukan luas permukaan dan volume bangun ruang sisi Datar (kubus, balok, prisma, dan limas).

Pada siklus kedua, aktivitas siswa pada saat presentasi juga mengalami peningkatan. Para siswa mulai berani mengungkapkan jawabannya sendiri-sendiri, hal ini ditunjukkan dengan adanya beberapa siswa yang menanggapi atau merespons pendapat kelompok yang melakukan presentasi, dengan materi 4.9 menyelesaikan masalah yang berkaitan dengan luas permukaan dan volume bangun ruang sisi datar (kubus, balok, prisma, dan limas). 
2. Berdasarkan analisis data diperoleh hal-hal sebagai berikut.

a. Dalam proses belajar mengajar dapat dilihat dari aktivitas guru dan siswa yang mengalami peningkatan melalui penerapan pembelajaran open ended, hal tersebut dapat dilihat dari pendidikan karakter siswa Kelas VIII D SMP Negeri 26 Surabaya adanya peningkatan dari skor perolehan pada siklus I 61,86 (sedang) dan pada siklus II menjadi 72,73 (tinggi). Demikian juga pada kualitas pembelajaran oleh guru matematika SMP Negeri 26 Surabaya juga mengalami peningkatan dari skor perolehan pada siklus I sebesar $65,00 \%$ (cukup) dan pada siklus II menjadi 76,00\% (baik).

b. Prestasi belajar siswa melalui hasil penelitian ini menunjukkan bahwa penerapan pembelajaran open ended memiliki dampak positif terhadap pemahaman tentang KD bangun ruang sisi datar. 3.9. Membedakan dan menentukan luas permukaan dan volume bangun ruang sisi datar (kubus, balok, prisma dan limas) dan 4.9 Menyelesaikan masalah yang berkaitan dengan luas permukaan dan volume bangun ruang sisi datar (kubus, balok, prisma dan limas), siswa VIII D SMP Negeri 26 Surabaya tahun pelajaran 2015-2016. Hal ini dapat dilihat dari semakin meningkatnya pemahaman dan penguasaan siswa terhadap materi yang telah disampaikan guru selama ini dengan nilai ratarata kelas 79,08 pada siklus pertama menjadi 89,47 pada siklus kedua. Sedang untuk ketuntasan belajar berdasarkan KKM (ketuntasan belajar meningkat dari siklus pertama dan siklus kedua), yaitu masing-masing $71,06 \%$ siklus pertama dan 86,85\% pada siklus kedua prestasi belajar siswa secara klasikal telah tercapai.

\section{Simpulan}

Berdasarkan hasil penelitian dengan penerapan metode pembelajaran open ended bermuatan pendidikan karakter pada siswa kelas VIII-D SMP Negeri 26 Surabaya tahun pelajaran 2015/2016 diperoleh simpulan sebagai berikut.

1. Hasil belajar peserta didik dengan menerapkan model pembelajaran open ended bermuatan pendidikan karakter mencapai 72,736 (tinggi) kriteria ketuntasan minimal (KKM) klasikal minimal 85\%.

2. Kemampuan pembelajaran oleh guru matematika dan pemecahan masalah peserta didik dalam model pembelajaran open ended bermuatan pendidikan karakter kualitasnya lebih tinggi hal ini dapat dilihat dengan capaian $76 \%$.

3. Semakin meningkatnya pemahaman dan penguasaan siswa terhadap materi pembelajaran open ended bermuatan pendidikan karakter yang telah disampaikan guru selama ini dengan nilai rata-rata kelas 86,37 . Sedang untuk ketuntasan belajar berdasarkan KKM (ketuntasan belajar) prestasi belajar siswa secara klasikal telah tercapai.

\section{Saran}

Berdasarkan simpulan di atas, saran dari peneliti adalah sebagai berikut.

1. Guru mata pelajaran matematika hendaknya melakukan variasi pembelajaran (baik model atau metode pembelajaran) dalam PBM untuk menunjang pembelajaran yang efektif agar tujuan pembelajaran dapat tercapai seperti yang diharapkan.

2. Penerapan metode pembelajaran open ended bermuatan pendidikan karakter pada siswa kelas VIII D SMP Negeri 26 Surabaya dapat dikembangkan untuk diterapkan pada materi 
Indah Sulistyaningsih, Penerapan Pembelajaran Open Ended untuk Mengetahui Hasil Belajar Peserta Didik pada Materi Bangun Ruang Sisi Datar Kelas VIII-D SMP Negeri 26 Surabaya Tahun Pelajaran 2015-2016

pokok mata pelajaran matematika lainnya dengan variasi dan inovasi dalam pembelajaran.

\section{DAFTAR PUSTAKA}

Amri, S. 2011. Implementasi Pendidikan Karakter dalam Pembelajaran. Jakarta: Prestasi Pustaka Publisher.

BSNP. 2006. Standar Isi untuk Satuan Pendidikan Dasar dan Menengah. Jakarta: BSNP.

Depdiknas. 2008. Strategi Pembelajaran dan Pemilihannya. Jakarta: Depdiknas.

Fachrurrazy. 2002. Pendekatan Konstruktivis untuk Pengajaran Reading Bahasa Inggris. Jurnal Pendidikan \& Pembelajaran. Jakarta: PT Rieneka Cipta.

Hapsari, T.S. 2011. Penerapan Model Pembelajaran Konstruktivisme untuk Meningkatkan Hasil Belajar IPA. Jurnal Pendidikan Penabur. Jakarta: Rajawali.

Suhardi. 2008. Pengaruh Pembelajaran Open Ended terhadap Prestasi Belajar.

Idrus, M. 2012. Pendidikan Karakter pada Keluarga Jawa. Jurnal Pendidikan Karakter, 2(2): 120 .

Inprasita, M. 2006. Open Ended Approach and Teacher Education. Journal of education study in mathematics Vol. 25, 169-177.

KBBI, Tim Penyusun. 2003. Kamus Besar Bahasa Indonesia. Jakarta: Balai Pustaka.

Kemendiknas. 2010. Pendidikan Karakter di Sekolah Menengah Pertama. Jakarta: Kemendiknas.
Kusmiyati \& R. Setiamihardja. 2007. Pendekatan Open Ended dalam Pembelajaran Matematika di Sekolah Dasar. Jurnal Pendidikan Dasar, No. 8: 1.

Leksono, J.T. 2006. Pengaruh Motivasi Belajar dan Kemampuan Berproses Pada Pembelajaran Pendekatan Open Ended terhadap Hasil Belajar Siswa pada Pokok Bahasan Persamaan Garis Lurus Kelas Viii SMP Negeri 4 Pati. Skripsi. Semarang: UNNES.

Marpaung, Y. 2003. Pendekatan Sosio Kultural dalam Pembelajaran Matematika. Yogyakarta: Kanisius.

Mumpuniarti. 2012. Pembelajaran Nilai Keberagaman dalam Pembentukan Pendidikan Karakter Siswa SD Inklusi. Jurnal Pendidikan Karakter, 2(3): 252.

Nasution. 2006. Metode Research (Penelitian Ilmiah). Jakarta: Bumi Aksara.

Nuharini, D \& T. Wahyuni. 2008. Matematika Konsep dan Aplikasinya. Jakarta: Depdiknas.

Sagala, S. 2006. Konsep dan Makna Pembelajaran. Bandung: CV Alfabeta.

Sardiman. 2008. Interaksi \& Motivasi Belajar Mengajar. Jakarta: Raja Grafindo Persada.

Sugiyono. 2010. Metode Penelitian Pendidikan. Bandung: Alfabeta.

Suparno. 1997. Filsafat Konstruktivisme dalam Pendidikan. Yogyakarta: Kanisius.

Winarti, Retno Endang. 2009. Bahan Ajar Mata Kuliah Evaluasi Proses dan Hasil Pembelajaran Matematika. Semarang: Universitas Negeri Semarang. 
Education and Human Development Journal, Vol. 3, No. 2, September 2018 